\title{
Leadership Analysis at a "Great Distance": Using the Operational Code Construct to Analyse Islamist Leaders
}

\author{
ÖZGÜR ÖZDAMAR
}

Operational code analysis was originally designed to analyse the Soviet Politburo members' political strategies and was codified by George and Walker, Schafer and Young. The approach has mostly been used to analyse individual world leaders, rather than specific political groups. In this article, I use the operational code construct to analyse political Islamists' belief systems. I discuss issues regarding using the operational code construct in a non-Western political and cultural setting. The first difficulty of using the operational code analysis to analyse political Islamists' strategies is the diversity of the movement, which led to a certain "level of analysis" problem. Second, whether to use computerised analysis or traditional hand coding was an important decision. Third, some procedures of the operational code research agenda, such as coding only transitive verbs, at times seemed to be in conflict with Turkish and Arabic sentence structures and verbs. Lastly, since the "Western" foreign policy analysis (FPA) theories are not frequently applied in the "global south" cases, I did not have a large body of literature to use while conducting my research. This article discusses the "boundedness" of the operational code analysis in analysis of non-Western individual leaders and political movements by discussion of these issues and others.

\section{Introduction}

Operational code analysis ${ }^{1}$ was originally designed by Nathan Leites to analyse Soviet Politburo members' political strategies, and was codified by Alexander George $^{2}$ and Walker, Schafer and Young. ${ }^{3}$ In his monograph The Operational Code of the Politburo, Leites deals with issues such as determining the Bolsheviks' rules and exploring the effects of Lenin's and Stalin's writings on that large political group. Leites' findings led him to make some generalisations and predictions about Politburo members' political moves. Operational code analysis was further developed, first by Alexander George ${ }^{4}$ and then by Walker, Schafer and

1. Nathan Leites, The Operational Code of the Politburo (New York: McGraw-Hill, 1951); Nathan Leites, A Study of Bolshevism (New York: Free Press, 1953).

2. Alexander L. George, "The Operational Code: A Neglected Approach to the Study of Political Leaders and Decision Making", International Studies Quarterly, Vol. 23, No. 2 (1969), pp. 190-222.

3. Stephen G. Walker, Mark Schafer and Michael D. Young, "Systematic Procedures for Operational Code Analysis: Measuring and Modeling Jimmy Carter's Operational Code", International Studies Quarterly, Vol. 42, No. 1 (1998), pp. 175-190.

4. George, "The Operational Code", op. cit. 
Young. ${ }^{5}$ Since George's call to revitalise the research agenda, it has mostly been used to analyse world leaders rather than political groups. ${ }^{6}$ The operational code construct has become an important research agenda for cognitively oriented decision-making researchers within the foreign policy analysis (FPA) literature. In this article, I use the operational code construct to analyse representative leaders of political groups that appear and operate in a region far from North America where this literature was born. That is, I use operational code analysis to analyse the belief systems of political Islamists in the Middle East and North Africa (MENA) and discuss difficulties associated with this endeavour.

Political Islam became an influential movement in the second half of the 20th century in the MENA. Built on classic Islamic sources, such as the Quran and the Sunna, Muslim history and modern political ideologies (such as socialism, nationalism and anti-capitalism) have also shaped the ideology. With the end of the Cold War, the political movement reasserted itself in democratic politics (such as in Turkey with the Welfare Party [RP] and the Justice and Development Party [AKP]) and also via illegal organisations (such as the Muslim Brotherhood in Egypt) and armed groups (such as Hezbollah) in the region and the rest of the world (e.g. the Pan Malaysian Islamic Party in Malaysia or the Prosperous Justice Party in Indonesia). All these movements, however, have been influenced by similar intellectual sources. In addition to the classic sources, followers of political Islam read Muslim authors such as Seyd Qutb, Ali Shariati, Mohammed al-Ghazali and Said Nursi, as well as politicians like Ruhollah Khomeini.

While using insights from the operational code literature to analyse belief systems of Islamists in the MENA, I encountered some issues regarding the theory, methodology and general applicability and boundedness of operational code analysis in and to different political and cultural settings. Although operational code analysis was originally developed to analyse a non-American group (the Bolshevik party in the USSR), modern methods tend to be technical and automated, and therefore problematic when applied to different political and cultural settings. The first difficulty in using operational code analysis to analyse political Islamists is the diversity of political Islam; it is neither cohesive like the Politburo, nor are there many individual Islamist leader examples from the same country. For these reasons, I encountered a certain "level of analysis" problem during my research; I had to compare different leaders operating in different polities. The second issue involves language. Modern quantitative operational code analysis is based on English texts and automated systems. When using an automated system, researchers gain in terms of reliability but lose considerably in terms of validity. Although hand coding also reveals mixed results, I decided to hand code the data due to the limitations of the automated system. Third, some procedures of the operational code research agenda, such as coding only transitive verbs, at times conflicted with Turkish and Arabic sentence structures and verbs. Finally, since Western FPA theories are not frequently applied in "global south" cases, I did not have a large body of literature to resort to while conducting my research.

This article discusses the boundedness of the operational code construct by analysing non-Western individual leaders and political movements. It begins with brief introductions to political Islam and operational code analysis to inform the

5. Walker, Schafer and Young, op. cit.

6. George, "The Operational Code", op. cit. 
reader about the subjects at hand. A summary of my research on the operational codes of original and neo-Islamists follows. Finally, I discuss theoretical, methodological and region-specific issues related to applying the operational code construct to Islamist leaders. I devote the final section to the debate on the boundedness of North American FPA theories by using insights from this research.

\section{Political Islam and Middle Eastern Politics}

Political Islam reappeared as a powerful political force in the MENA during the second half of the 20th century. Although it is certainly not a "monolithic phenomenon", 7 partly as a reaction to colonisers and the superpower penetration of the region, and partly as a reaction to the failure of domestic secular nationalist movements to achieve political and economic development, political Islam regained strength especially after the late 1960s. ${ }^{8}$ Islamist movements achieved success in Iran, Lebanon, Palestine and Libya, were harshly suppressed in Algeria and Egypt, and have produced coalition partners and election-winning catch-all parties in Turkey.

For scholars of Islam and the Middle East, there has never been a clear distinction between religion and the state in the classical Islamic tradition. This was reflected in the Muslim empires' foreign policy, conception of war and peace, and international law. ${ }^{9}$ Islamic concepts were-to some extent-taken into consideration when making decisions in these foreign policy-related issues. Yet, with the Iranian revolution and its aftermath, when researchers attempted to understand the influence of Islam on foreign policy decisions, they did not succeed completely due to the underdevelopment of political science methodologies to evaluate Islamic influences on policy. ${ }^{10}$ There have been attempts, however, from both the Islamic world ${ }^{11}$ analysing foreign affairs from a purist Islamic perspective and from Western academics ${ }^{12}$ using mainstream Western geopolitical theories. Nevertheless, literature on Islam's influence on foreign policy in predominantly Muslim countries remains in its infancy. After 9/11, the US-led wars in Afghanistan and Iraq, and the Arab uprisings since 2011, there has been a resurgent interest in the subject.

A few studies that deal with non-Western leadership by using the operational code construct have been conducted in the last two decades, although they do not focus on political Islam per se. Crichlow uses the operational code construct to analyse whether beliefs have an impact on Israeli foreign policy decisions. ${ }^{13}$ The results showed fluctuating beliefs due to changing dynamics in the Middle East and in the world. Dyson has used the operational code construct to analyse

7. Muhammad Ayoob, "The Future of Political Islam: The Importance of External Variables", International Affairs (Royal Institute of International Affairs 1944-), Vol. 81, No. 5 (2005), pp. 951-961. Retrieved from http://www.jstor.org/stable/3569069.

8. Anthony Black, The History of Islamic Political Thought: From the Prophet to the Present (New York: Routledge, 2001).

9. Bernard Lewis, The Political Language of Islam (Chicago, IL: University of Chicago Press, 1991); Bernard Lewis, The Middle East: The Brief History of the Last 2,000 Years (New York: Scribner, 1995).

10. Adeed Dawisha, Islam in Foreign Policy (Cambridge: Cambridge University Press, 1983).

11. Abdul Hamid Abu Suleyman, The Islamic Theory of International Relations: New Directions for Islamic Methodology and Thought (Herndon, VA: International Institute of Islamic Thought, 1987).

12. Graham E. Fuller and Ian O. Lesser, A Sense of Siege: The Geopolitics of Islam and the West (Boulder, CO: Westview, 1995).

13. Scott Crichlow, "Idealism or Pragmatism? An Operational Code Analysis of Yitzhak Rabin and Shimon Peres", Political Psychology, Vol. 19, No. 4 (1998), pp. 683-706. 
then-new Russian leader Vladimir Putin. ${ }^{14}$ Feng analyses Chinese leaders vis-à-vis the straits crisis. ${ }^{15}$ Malici and Malici have focused on two communist leadersFidel Castro and Kim Il Sung - to analyse whether the end of Cold War made any change to their beliefs about the political universe and their tactics. ${ }^{16}$ Their results show there was only a modest change despite the systemic shifts. Malici and Buckner show that seemingly "rogue" leaders are not as hostile as conventional wisdom suggests and that they have tactics designed to avert escalation and crisis. ${ }^{17}$ Devlen uses operational code analysis to analyse the Iranian nuclear programme row. ${ }^{18}$ Devlen's analysis suggests that although Iranians are keen to negotiate with the US, their general view of the US is very conflictual, which prevented engagement in constructive diplomacy. Similarly, O'Reilly suggests that beliefs have a direct impact on even the most strategic decisions such as nuclear proliferation. ${ }^{19}$ His study focuses on South African and Indian decision-making in regard to building nuclear weapons, and supports the notion that actors' perception of the international system is more important than abstract notions such as the security dilemma when making the most strategic decisions. Even though there have been some examples of operational code analysis in non-Western cases, application of the construct to Muslim leaders has been very rare, with Malici and Buckner one of the few exceptions. ${ }^{20}$

Despite its importance in the MENA in the last half-century, political Islam is also understudied. Most studies that analyse these movements suffer either from political and cultural biases or a lack of understanding about the region. In the FPA literature, few studies focus on political Islam as a distinct political ideology with specific foreign policy preferences. This research aims to fill the gap. ${ }^{21} \mathrm{I}$ believe that the micro-level analysis of FPA offers some of the most powerful methodologies to approach the question of political Islam's influence on foreign policy. More specifically, FPA allows us to see this linkage through the analysis of leader beliefs. Accordingly, this study will analyse the belief systems of Islamist leaders. First, I focus on three Islamist leaders of the previous generation: Necmettin Erbakan of Turkey, Imam Khomeini of Iran, and Moammer Qaddafi of Libya. I then turn to neo-Islamists

14. Stephen Benedict Dyson, "Drawing Policy Implications from the 'Operational Code' of a 'New' Political Actor: Russian President Vladimir Putin”, Policy Sciences, Vol. 34, No. 3/4 (2001), pp. 329-346, available: <http://www.jstor.org/stable/4532539>.

15. Huiyun Feng, "Crisis Deferred: An Operational Code Analysis of Chinese Leaders across the Strait", in Mark Schafer and Stephen Walker (eds.), Beliefs and Leadership in World Politics: Methods and Applications of Operational Code Analysis (New York: Palgrave Macmillan, 2006), pp. 151-170.

16. Akan Malici and Johnna Malici, "The Operational Codes of Fidel Castro and Kim Il Sung: The Last Cold Warriors?", Political Psychology, Vol. 26, No. 3 (2005), pp. 387-412, available: <http://www.jstor.org/ stable/3792603>.

17. Akan Malici and Allison L. Buckner, "Empathizing with Rogue Leaders: Mahmoud Ahmadinejad and Bashar al-Asad", Journal of Peace Research, Vol. 45, No. 6 (2008), pp. 783-800.

18. Balkan Devlen, "Dealing or Dueling with the United States? Explaining and Predicting Iranian Behavior during the Nuclear Crisis", International Studies Review, Vol. 12, No. 1 (2010), pp. 53-68, available: <http://www.jstor.org/stable/40730709>.

19. K.P. O'Reilly, "Leaders' Perceptions and Nuclear Proliferation: A Political Psychology Approach to Proliferation", Political Psychology, Vol. 33, No. 6 (2012), pp. 767-789, available: <http://www.jstor.org/ stable/23324191>.

20. Malici and Buckner, op. cit.

21. This research about the belief systems of political Islamists was presented at the annual meetings of the International Studies Association in 2011 and 2012. It is still in progress and not published elsewhere. In this article, a summary of the research process and broad conclusions are presented. 
and perform an operational code analysis of Prime Minister Tayyip Erdoğan of Turkey, Mahmoud Ahmadinejad of Iran, and Khalid Meshal of Gaza. To analyse these leaders' belief systems about foreign policy, I use the operational code approach.

\section{Operational Code: Beliefs and Strategies}

Operational code analysis focuses on the beliefs of political leaders as causal mechanisms in explaining foreign policy decisions. It was originally developed by Leites $^{22,23}$ to analyse the decision-making style of the members of the Soviet Politburo and later refined by George, ${ }^{24,25}$ Holsti $^{26}$ and Walker ${ }^{27,28}$. According to the operational code construct, a leader's cognitive schema or belief system has two components. The first set contains five philosophical beliefs about the leader's political universe and the nature of the "other" he or she faces in this environment. The second set holds five instrumental beliefs that represent the image of "self" in this political universe and the best strategies and tactics a leader could employ to achieve his or her ends. ${ }^{29}$ Taken together, the two sets explain decision-makers' tendencies on foreign policy. ${ }^{30}$

A leader's philosophical and instrumental beliefs are the answers to a set of questions developed by George. ${ }^{31}$ Regarding philosophical beliefs, the questions are:

P-1. What is the "essential" nature of political life? Is the political universe essentially one of harmony or conflict? What is the fundamental character of one's political opponents?

P-2. What are the prospects for the eventual realisation of one's fundamental values and aspirations? Can one be optimistic, or must one be pessimistic on this score, and in what respects the one and/or the other?

P-3. Is the political future predictable? In what sense and to what extent?

P-4. How much "control" or "mastery" do self and other have over historical development? What is self and other's role in "moving" and "shaping" history in the desired direction?

P-5. What is the role of "chance" in human affairs and in historical development?

Concerning instrumental beliefs, the questions are:

I-1. What is the best approach for selecting goals or objectives for political action?

22. Leites, "The Operational Code", op. cit.

23. Leites, "A Study of Bolshevism", op. cit.

24. George, "The Operational Code", op. cit.

25. Alexander L. George, "The Causal Nexus between Beliefs and Behavior", in Lawrence S. Falkowski (ed.), Psychological Models in International Politics (Boulder, CO: Westview, 1979), pp. 95-124.

26. Ole Holsti, "The Operational Code as an Approach to the Analysis of Belief Systems", Final Report to the National Science Foundation (1977), Grant No. SOC 75-15368.

27. Walker G. Stephen, "The Motivational Foundations of Political Belief Systems: A Re-analysis of the Operational Code Construct", International Studies Quarterly, Vol. 27, No. 2 (1983), pp. 179-201.

28. Stephen G. Walker, “The Evolution of Operational Code Analysis”, Political Psychology, Vol. 11, No. 2 (1990), pp. 403-418.

29. George, "The Causal Nexus", op. cit.; Walker, "The Evolution of", op. cit.

30. Schafer and Walker, op. cit.

31. George, "The Operational Code", op. cit.; George, "The Causal Nexus", op. cit. 
I-2. How are the goals of action pursued most effectively?

I-3. How are the risks of political action calculated, controlled and accepted?

I-4. What is the best "timing" of action to advance one's interests?

I-5. What is the utility and role of different means for advancing one's interests?

P-1, I-1 and P-4 are considered master beliefs; they are key in determining the answers to the other questions. The central assumption of operational code analysis is that individual leaders matter in shaping states' foreign policies and that the beliefs a leader has might act as causal mechanisms in understanding why he or she chooses a certain foreign policy decision. Conversely, mainstream international relations theories (such as neorealism) rule out diversities in leaders' beliefs, their effects on foreign policy behaviour, and leaders' misperceptions of their states' positions as causes of leaders' effects on the international system. ${ }^{32}$

Trying to answer George's questions about philosophical and instrumental beliefs, ${ }^{33}$ Holsti developed six types of operational codes (A, B, C, D, E, F), ${ }^{34}$ which Walker later reduced to four (A, B, C, DEF), op. cit. $^{35}$ This typology is based on the nature (temporary versus permanent) and the source (individual/ society/international system) of conflict in the political world, deduced from the answers to P-1, I-1 and P-4. ${ }^{36}$ In the revised typology, pessimists (DEF types), who see conflict as permanent, are defined as a single group regardless of the source of that conflict. Walker argues that such a move is justified because there are no discernible differences in the remaining philosophical and instrumental beliefs of DEF types, thus they can be seen as a single ideal type. ${ }^{37}$ Optimists, however, differ in how they see the source of conflict: misperceptions by the individuals (A), societal institutions (B) or the anarchic nature of the international system (C). Those differences have an impact on the rest of the leader's philosophical and instrumental beliefs. ${ }^{38}$ Table 1 represents this typology.

The four quadrants that represent six different leadership types also propose a specific preference ordering for each type. Modern operational code analysis subscribes to a via media position in the rational choice-cognitive theories debate and incorporates strengths of both. The main argument of operational code analysis is that preferences are not fixed for agents as rational choice theory assumes. By focusing on specific belief systems of leaders, researchers can infer actors' preferences in a more robust fashion. The leadership types and corresponding preference orderings are in line with the main assumptions of operational code analysis and game theory research. Type $\mathrm{A}$ and $\mathrm{C}$ leaders, who have a more friendly orientation, prefer to settle their differences with political opponents rather than resorting to domination, deadlock or submission. Type B and DEF leaders prefer domination over other preferences. These preference orders are used to construct various $2 \times 2$

32. Schafer and Walker, op. cit., p. 8.

33. George, "The Operational Code", op. cit.

34. Ole Holsti, "The Operational Code", op. cit.

35. Stephen G. Walker, "The Motivational Foundations of Political Belief Systems: A Reanalysis of the Operational Code Construct", International Studies Quarterly, Vol. 27, No. 2 (1983), pp. 179-201; Walker, "The Evolution of Operational Code Analysis", op. cit.

36. Schafer and Walker, op. cit.

37. Walker, "The Motivational Foundations", op. cit.

38. Walker, Schafer and Young, op. cit. 
Table 1. Contents of the Revised Holsti Operational Code Typology.

TYPE A

Conflict is temporary, caused by human misunderstanding and miscommunication. A "conflict spiral", based upon misperception and impulsive responses, is the major danger of war. Opponents are often influenced in kind to conciliation and firmness. Optimism is warranted, based upon a leader's ability and willingness to shape historical development. The future is relatively predictable, and control over it is possible. Establish goals within a framework that emphasises shared interests. Pursue broadly international goals incrementally with flexible strategies that control risks by avoiding escalation and acting quickly when conciliation opportunities arise.

Emphasise resources that establish a climate for negotiation and compromise and avoid the early use of force.

Settle $>$ Deadlock $>$ Dominate $>$ Submit
TYPE C

Conflict is temporary; it is possible to restructure the state system to reflect the latent harmony of interests. The source of conflict is the anarchical state system, which permits a variety of causes to produce war. Opponents vary in nature, goals and responses to conciliation and firmness. One should be pessimistic about goals unless the state system is changed, because predictability and control over historical development are low under anarchy. Establish optimal goals vigorously within a comprehensive framework. Pursue shared goals, but control risks by limiting means rather than ends. Act quickly when conciliation opportunities arise and delay escalatory actions whenever possible. Resources other than military capabilities are useful.

Settle $>$ Dominate $>$ Deadlock $>$ Submit

\section{Dominate $>$ Settle $>$ Deadlock $>$ Submit}

Conflict is permanent, caused by human nature

(D), nationalism (E) or international anarchy

(F). Power disequilibria are major dangers of war. Opponents may vary, and responses to conciliation or firmness are uncertain. Optimism declines over the long run and in the short run depends upon the quality of leadership and a power equilibrium. Predictability is limited, as is control over historical development. Seek limited goals flexibly with moderate means. Use military force if the opponent and circumstances require it, but only as a final resource.
Dominate $>$ Deadlock $>$ Settle $>$ Submit

Conflict is temporary, caused by warlike states; miscalculation and appeasement are the major causes of war. Opponents are rational and deterrable. Optimism is warranted regarding realisation of goals. The political future is relatively predictable, and control over historical development is possible. One should seek optimal goals vigorously within a comprehensive framework. Control risks by limiting means rather than ends. Any tactic and resource may be appropriate, including the use of force when it offers prospects for large gains with limited risks.

TYPE B

\section{TYPE DEF}

Note: Instrumental beliefs are in bold, and philosophical beliefs are not.

Source: Stephen G. Walker, "The Motivational Foundations of Political Belief Systems: A Reanalysis of the Operational Code Construct", International Studies Quarterly, Vol. 27, No. 2 (1983), pp. 179-201;

Stephen G. Walker, "The Evolution of Operational Code Analysis", Political Psychology, Vol. 11, No. 2 (1990), pp. 403-418.

games to represent and predict different strategic situations by using Brams' Theory of Moves approach. Brams' typology is generic enough to appeal to researchers outside of North America. ${ }^{39}$ However, given the general unavailability

39. Steven Brams, Theory of Moves (Cambridge: Cambridge University Press, 1994). 
of training in quantitative political science and FPA outside of North America, game theory is rarely used in the academia of the MENA region.

Contemporary operational code analysis uses an automated content analysis method called the "Verbs in Context System" (VICS), introduced by Walker, Schafer and Young. ${ }^{40}$ This system focuses on the verbs in a leader's public statements and their attributions regarding the exercise of power to self and others to construct quantitative indices that correspond to the philosophical and instrumental beliefs shown in Table 2. ${ }^{41}$ The VICS indices for the master beliefs, P-1 (nature of the political universe), I-1 (strategic approach to goals) and P-4 (ability to control historical development), are mapped on the vertical (P-1/I-1) and horizontal (P-4) axes in Table 1 to locate the leader's images of self and other in one of the four quadrants. The locations for self ( $\mathrm{I}-1, \mathrm{P}-4 \mathrm{a})$ and other $(\mathrm{P}-1, \mathrm{P}-4 \mathrm{~b})$ lead to predictions regarding strategic preferences about the goals of settle, submit, dominate and deadlock. ${ }^{42}$ Table 2 provides details about calculating VICS indices.

Walker and Schafer further refined the preference orderings based on the key operational code indices and developed a "theory of inferences about preferences". ${ }^{43}$ Inferences are made by comparing the leader's key operational code scores (P-1, I-1 and P-4) with a norming sample of world leaders (see Table 3). If the index scores lie above (below) this norm, the index is considered positive (negative) for the purposes of inferring preferences. For the P-4 index, a norming range of one standard deviation was set, and the index is interpreted by looking at whether the score is within one standard deviation of the norming mean or outside of it. ${ }^{44}$

In my research, due to a limited number of speeches in English, I chose to perform hand coding. Therefore, I could use Turkish texts and texts translated into Turkish from Arabic and Farsi. To simplify the research and therefore achieve more reliable results, I coded only positive/negative attributes about self/ other. These variables were enough to determine the operational code master beliefs: P-1, I-1 and P-4. As will be discussed later in this article, this simpler approach achieved high levels of intercoder reliability.

There is still an ongoing debate in the scholarly community about whether hand coding has more advantages over the automated system. ${ }^{45}$ I suggest that there is a trade-off between validity and reliability of coding depending on the specific method used. Like many operational code analysis researchers who have conducted both computerised and hand coding, I argue that properly executed hand coding is significantly more valid than the computer-based analysis. The reason is that even after two decades of development, Profiler Plus software is not capable of coding verbs in context $100 \%$ correctly. This is not a problem specific to only Profiler Plus and operational code research. Other fields, such as in computer science, also lack complete accuracy in natural language processing (NLP). After

40. Walker, Schafer and Young, op. cit.

41. Schafer and Walker, op. cit.

42. Ibid.

43. Ibid.

44. Ibid.

45. Henk E. Goemans, Kristian Skrede Gleditsch and Giacomo Chiozza, “Introducing Archigos: A Dataset of Political Leaders", Journal of Peace Research, Vol. 46, No. 2 (2009), pp. 269-283; Margaret G. Hermann, Assessing Leadership Style: A Trait Analysis (Social Science Automation System, 1999); M. Schafer, "Issues in Assessing Psychological Characteristics at a Distance: An Introduction to the Symposium", Political Psychology, Vol. 21, No. 3 (2000), pp. 511-527, available: <http://www.jstor.org/stable/ 3791848>. 
Table 2. "Verbs in Context" Belief Indices in a Leader's Operational Code.

\begin{tabular}{|c|c|c|c|}
\hline P-1 & $\begin{array}{l}\text { NATURE OF THE POLITICAL } \\
\text { UNIVERSE (Image of others) }\end{array}$ & $\begin{array}{l}\text { \%Positive minus } \\
\% \text { Negative Transitive Other Attributions }\end{array}$ & $\begin{array}{l}+1.0 \text { friendly to } \\
-1.0 \text { hostile }\end{array}$ \\
\hline & VALUES (Optimism/Pessimism) & Other Attributions divided by 3 & -1.0 pessimistic \\
\hline P-3 & $\begin{array}{l}\text { POLITICAL FUTURE } \\
\text { (Predictability of others' tactics) }\end{array}$ & $\begin{array}{l}1 \text { minus Index of Qualitative } \\
\text { Variation for Other Attributions }\end{array}$ & $\begin{array}{l}1.0 \text { predictable to } \\
0.0 \text { uncertain }\end{array}$ \\
\hline P-4 & $\begin{array}{l}\text { HISTORICAL DEVELOPMENT } \\
\text { (Locus of control) }\end{array}$ & $\begin{array}{l}\text { Self (P-4a) or Other (P-4b) Attributions } \\
\text { divided by [Self plus Other Attributions] }\end{array}$ & $\begin{array}{l}1.0 \text { high to } \\
0.0 \text { low self-control }\end{array}$ \\
\hline P-5 & $\begin{array}{l}\text { ROLE OF CHANCE } \\
\text { (Absence of control) }\end{array}$ & $\begin{array}{l}1 \text { minus [Political FuturexHistorical } \\
\text { Development Index] }\end{array}$ & $\begin{array}{l}1.0 \text { high role to } \\
0.0 \text { low role }\end{array}$ \\
\hline I-2 & $\begin{array}{l}\text { PURSUIT OF GOALS } \\
\text { (Intensity of tactics) }\end{array}$ & $\begin{array}{l}\text { Mean Intensity of Transitive Self } \\
\text { Attributions divided by } 3\end{array}$ & $\begin{array}{l}+1.0 \text { high cooperation to } \\
-1.0 \text { high conflict }\end{array}$ \\
\hline I-3 & $\begin{array}{l}\text { RISK ORIENTATION } \\
\text { (Predictability of tactics) }\end{array}$ & $\begin{array}{l}1 \text { minus Index of Qualitative } \\
\text { Variation for Self Attributions }\end{array}$ & $\begin{array}{l}1.0 \text { risk acceptant to } \\
0.0 \text { risk averse }\end{array}$ \\
\hline I-4 & $\begin{array}{l}\text { TIMING OF ACTION } \\
\text { (Flexibility of tactics) } \\
\text { a. Coop v. Conf tactics } \\
\text { b. Word v. Deed tactics }\end{array}$ & $\begin{array}{l}1 \text { minus Absolute Value } \\
{[\% X \text { Minus \%Y Self Attributions] }} \\
\text { Where } X=\text { Coop and } Y=\text { Conf } \\
\text { Where } X=\text { Word and } Y=\text { Deed }\end{array}$ & $\begin{array}{l}1.0 \text { high to } \\
0.0 \text { low shift propensity }\end{array}$ \\
\hline
\end{tabular}

Note: All indices vary between 0 and 1.0 except for P-1, P-2, I- 1 and I-2, which vary between 1.0 and p 1.0. P-2 and I-2 are divided by 3 to standardise the range. Source: Stephen G. Walker, Mark Schafer and Michael D. Young, "Systematic Procedures for Operational Code Analysis: Measuring and Modeling Jimmy Carter's Operational Code", International Studies Quarterly, Vol. 42, No. 1 (1998), pp. 175-190. 
Table 3. Norming Scores and Inferences.

\begin{tabular}{lclll}
\hline Self & Other & Values & & Preference Order in a 2×2 Strategic Game \\
\hline I-1 \& P-4a & P-1 \& P-4b & $+\&>$ & Settle $>$ Deadlock $>$ Submit $>$ Dominate (Appease) \\
I-1 \& P-4a & P-1 \& P-4b & $+\&=$ & Settle $>$ Deadlock $>$ Dominate $>$ Submit (Deter $/$ Reward) \\
I-1 \& P-4a & P-1 \& P-4b & $+\&>$ & Settle $>$ Dominate $>$ Deadlock $>$ Submit (Exploit) \\
I-1 \& P-4a & P-1 \& P-4b & $-\&<$ & Dominate $>$ Settle $>$ Submit $>$ Deadlock (Bluff) \\
I-1 \& P-4a & P-1 \& P-4b & $-\&=$ & Dominate $>$ Settle $>$ Deadlock $>$ Submit (Punish $/$ Compel) \\
I-1 \& P-4a & P-1 \& P-4b & $-\&>$ & Dominate $>$ Deadlock $>$ Settle $>$ Submit (Bully) \\
\hline
\end{tabular}

Note: "+" indicates above and " - " indicates below the norming mean; " $<,>,=$ " indicate below, above or within the norming average range, which is $\mathrm{P}-4 \mathrm{a} \pm 1 \mathrm{SD}$. The mean values for the norming group of world leaders are: $\mathrm{P}-1=+.30, \mathrm{SD}=.29 ; \mathrm{I}-1=+.40, \mathrm{SD}=.43 ; \mathrm{P}-4=.22, \mathrm{SD}=.13$.

Source: Akan Malici and Allison L. Buckner, "Empathizing with Rogue Leaders: Mahmoud Ahmadinejad and Bashar al-Asad", Journal of Peace Research, Vol. 45, No. 6 (2008), pp. 783-800.

seven decades of research, computer scientists still struggle with creating efficient platforms to help interactions between human languages and computers. Today most NLP tools are based on a set of handwritten rules (as is Profiler Plus). These tools are still not as accurate as humans when coding a specifically focused text such as in operational code studies analysis in political science. Perhaps this will change as computer-based analysis takes a more "machine learning" direction. Especially in MENA political settings, where political speeches are very colourful, witty, sarcastic, indirect and reproachful, researchers are better off resorting to hand coding to capture the details and meaning of speeches. The advantage of computer-based analysis is, of course, a maximum level of reliability. Because computers make coding based on the same set of rules each time, the same procedure is applied to each text regardless of culture, political bias or linguistic problems. Computerised coding also allows for norming group comparison because of the reliability. In this research, however, one cannot compare results to world leaders' norming group scores due to reliability problems. Only results obtained from the automated VICS system are comparable to each other. Therefore, while I can compare these leaders to one another using my hand coded results, I cannot strictly compare them to the VICS norming group scores.

\section{Case Selection}

Political Islam is not a monolithic movement; neither is it static. Furthermore, countries' historical backgrounds and political cultures have shaped the nature of the different movements. Yet, I argue that there are overarching themes and patterns of Islamist foreign policy beliefs and perceptions. To capture the diversity and the ideological similarities of the beliefs, I chose comparable leaders in terms of the period in which they operated and with respect to the representation of different ethnicities. I present the reasons for these choices below.

First, the three "old school" leaders (Erbakan, Qaddafi, and Khomeini) represent the three major ethnicities in the Muslim MENA: Arab, Persian and Turkish. Second, they come from countries with very different political backgrounds. While Iran experienced the earliest example of constitutional monarchy in the region, it went through the Pahlavi dynasty's authoritarianism for about six 
decades, before the Islamic revolution overthrew the monarchy. Libya has never experienced democratic rule (except for the interim regime since the death of Qaddafi in 2011) and in modern history has been governed by the Ottoman Empire, Italy or local monarchs. Turkey, on the other hand, has enjoyed a multiparty democratic system since 1946, albeit interrupted by four military coups between 1960 and 1997.

In terms of religious differences, Iran has been the only overtly Shia country in the region, while Turkey and Libya are predominantly Sunni. Regarding the time period, the three leaders were all active when Islamist leaders first came to power in the MENA, i.e. during the 1970s and 1980s. ${ }^{46}$ I only coded speeches from these two decades because the end of the Cold War changed the system structure as well as perceptions. Moreover, Khomeini died in 1989. The most important reason for my selection of these three leaders is that they were overt Islamists and used their own mixtures of Islam and other schools of thought and nationalism.

In my selection of neo-Islamists, I use similar criteria. Erdoğan represents political Islam in a democratic country, namely Turkey. Ahmadinejad and Meshal also perform in some sort of electoral politics, yet one cannot really say that Iran and Gaza are truly democratic. In terms of religious differences, Erdoğan and Meshal represent Sunni Islam and Ahmadinejad represents the Shia. The three leaders' biographies and their political/religious experiences are also strikingly similar.

Erdoğan was born in 1954 in Rize, a small city in north-eastern Turkey. He became involved in Turkey's rising political Islamist movement and met Erbakan, by then a prominent political figure in the Islamic movement and who became the country's first Islamist prime minister. ${ }^{47}$ In 1994, Erdoğan became mayor of Turkey's largest city, Istanbul. He established a new party (AKP) and became its leader in August 2001. Since then, Erdoğan has increased his share of votes, obtaining $49.8 \%$ of the popular vote in 2011 and 52\% in 2014, in addition to becoming an important political figure abroad, especially in the MENA countries.

Ahmadinejad was born to a middle class Persian family living in the village of Aradan in Semnan province in $1958 .{ }^{48} \mathrm{He}$ studied civil engineering at the Iran University of Science and Technology in Tehran. His early political life began with student movements in Tehran. In the 2005 general elections, he was the strongest conservative candidate for the presidency of Iran, garnering the support of the Supreme Leader Ali Khamenei. Following a populist election campaign, he took $62 \%$ of the votes and became the sixth president of the Islamic Republic of Iran. During his first term in office, he followed an aggressive foreign policy against Israel. After a controversial general election in 2009, he once again was elected but he failed to secure presidential nomination by the clergy in the 2014 elections. Ahmadinejad is considered to be one of the new conservatives in Iranian politics and the MENA, therefore fitting the aim of this analysis to analyse later representatives of political Islam in the region.

46. Qaddafi came to power in 1969 with a military coup. Erbakan was appointed deputy prime minister in 1973. Khomeini came to power with the Islamic revolution in 1979.

47. "Profile: Recep Tayyip Erdoğan", BBC (18 July 2007), available: <http://news.bbc.co.uk/2/hi/ europe/6900616.stm> (accessed 22 March 2012).

48. “Iran's President Launches Weblog", BBC (14 August 2006), available: <http://news.bbc.co.uk/2/hi/ middle_east/4790005.stm> (accessed 18 March 2012). 
Finally, Meshal was born in 1956 in Ramallah, Palestine. In 1967, after the Israeli occupation, his family moved to Kuwait, a hotbed of pro-Palestinian activism and Arab nationalism during the 1970s. ${ }^{49}$ Meshal became involved in the Islamic and Palestinian causes as well as in Arab nationalism at an early age, and became a member of the Muslim Brotherhood in 1971. Later, while he was studying physics at Kuwait University, he established a radical student group known as the "List of the Islamic Right", in which he orchestrated a robust campaign against Yasser Arafat's Palestine Liberation Organization (PLO). ${ }^{50}$ Meshal was still leader of this group when the Palestinian resistance movement Hamas was founded in 1987 after the Intifada, the first Palestinian uprising against Israeli occupation. Hamas aims to end the Israeli occupation of Palestinian territories and unify formerly invaded territories under the authority of one Palestinian state in conformity with the 1967 borders. Meshal became chairman of the Hamas Political Bureau in 1996, which criticised Arafat for his weakness and inertia vis-à-vis Israel's aggression and oppression of the Palestinian community. In 1997, Meshal was the target of an assassination attempt authorised by Israel's Netanyahu administration, which described Meshal as the leading figure in Hamas and blamed him for the murder of innocent Israeli civilians in the Palestinian suicide bombings. ${ }^{51}$ In 1999, King Abdullah closed all the Hamas offices in Jordan and Meshal was imprisoned, and deported shortly thereafter. ${ }^{52} \mathrm{He}$ is still the political chief of Hamas.

These brief introductions to the three neo-Islamist leaders' lives show significant similarities. All three are from modest backgrounds, college educated, religiously raised, and have been active in and around religious institutions. All three rose up against the established order in their respective countries and used religion as a significant aspect of their political mobilisation tactics.

\section{Research Design}

I used a collection of speeches, book chapters, books written by the respective leaders, and press conferences from the late 1960s to 1990 (but mostly from the 1970s and 1980s) to measure the operational codes of Erbakan, Khomeini and Qaddafi. I coded 14 different sources. Erbakan's speeches are taken from a compilation of his important speeches on foreign policy issues. Khomeini's speeches are taken from the Islamic Republic of Iran's website on Khomeini and a book of his speeches from the early 1960s until 1981. Finding Qaddafi's original speeches from this period proved difficult. I used a book that combined a rather long theoretical treatise on capitalism and colonialism, Qaddafi's "third universal theory" and his (long) interviews with international journalists and academics from 1973. All material concerns foreign policy issues, international relations or history in general, or the political economy of Muslim countries, focusing on foreign

49. "Profile: Khaled Meshaal", Al Jazeera (18 April 2008), available: <http://www.aljazeera.com/news/ middleeast/2008/04/20086150597219693.html> (accessed 22 March 2012).

50. "Profile: Khaled Meshaal of Hamas", BBC (8 February 2006), available: <http://news.bbc.co.uk/2/ hi/middle_east/3563635.stm> (accessed 22 March 2012).

51. "Profile of Khaled Meshaal", Council on Foreign Relations (13 July 2006), available: <http://www. cfr.org/terrorist-leaders/profile-khaled-meshal-aka-khalid-meshaal-khaleed-mashal/p11111> (accessed 22 March 2012).

52. "Profile: Khaled Meshaal of Hamas", op. cit. 
economic relations. To measure Erbakan's operational code, I coded six relatively long speeches and detected 413 self/other attributions. For Khomeini, I found 352 attributions in five speeches. For Qaddafi, in two long chapters that included more than 20,000 words, I found 284 verbs and other attributions. All speeches contained at least 20 coded verbs, as suggested by Schafer and Walker. ${ }^{53}$

Ahmadinejad's speeches are from the second half of the 2000s, with four from UN General Assembly meetings and three from interviews with journalists. I coded 286 self/other attributions from a total of 17,141 words. The sources for Meshal's speeches are mostly interviews with international media, which included a total of 13,929 words. There are seven Meshal speeches coded, with a total of 349 attributions. Erdoğan's speeches are taken from the AKP website. In a total of 10 speeches (comprising 21,932 words), 372 negative/positive and self/other attributions were coded. Because I coded all sources by hand, the results cannot be compared to the computer-based norming group scores, ${ }^{54}$ though they may be compared to one another in the hand coded set. This issue will be discussed in the next section.

The title, source and language of each speech, and the results obtained from them, are provided in an appendix. The speeches were selected according to criteria proposed by Walker et al. (each speech is at least 1,000 words and includes at least 20 transitive verbs) and their availability. ${ }^{55}$ Two large libraries in Ankara (Bilkent University Library and the National Library of Turkey), relevant embassy libraries in Ankara (such as the Iranian and Libyan embassies) and internet sources were searched and all the available speeches that fulfilled Walker et al.'s criteria ${ }^{56}$ have been used. Only in the case of Qaddafi did the number of speeches not fit the criteria due to a lack of his available speeches. However, I have included Qaddafi because the volume of two book chapters written by him exceeds the word limit criteria suggested by Walker et al. ${ }^{57}$ All speeches were coded by the author and two research assistants, and intercoder reliability checks were conducted.

\section{Results}

The analysis reveals interesting and consistent results about Islamist leaders' operational codes. Tables 4 and 5 present numeric results from hand coding of the six leaders' speeches. The three original Islamist leaders' self-images fall under quadrant A, as Figure 1 shows. That is, Erbakan's, Qaddafi's and Khomeini's selfimages range from definitely cooperative to very cooperative, with low historical control. $^{58}$ All three leaders' self-images are clearly within the Type A category, with a high cooperative outlook and personal sense of control. Type A leaders have a relatively friendly strategic orientation and a relatively low sense

53. Schafer and Walker, op. cit.

54. Ibid.

55. Walker, Schafer and Young, op. cit.

56. Ibid.

57. Ibid.

58. In many operational code studies, a norming group comparison has not been made until very recently. Instead researchers relied on categories based on absolute operational code scores. For example, P-4 categories are very low (at 0), low (at 0.25), medium (at 0.50 ), high (at 0.75 ) and very high (at 1.0). Every score in between is reported as an interval. For example, if a leader's P-4a score equalled 0.40 , this would be reported as "low to medium" (Walker, Schafer and Young, op. cit.). 
Table 4. Master Beliefs Scores for "Original Islamists": Erbakan, Qaddafi and Khomeini.

\begin{tabular}{lllll}
\hline & P-1 & I-1 & P-4a & P-4b \\
\hline Erbakan & -0.82 & 0.8 & 0.34 & 0.66 \\
Khomeini & -0.89 & 0.44 & 0.24 & 0.76 \\
Qaddafi & -0.95 & 0.62 & 0.28 & 0.72 \\
\hline
\end{tabular}

Table 5. Master Beliefs Scores for "Neo-Islamists": Erdoğan, Ahmadinejad and Meshal.

\begin{tabular}{lcccc}
\hline & P-1 & I-1 & P-4a & P-4b \\
\hline Erdoğan & -0.73 & 0.90 & 0.46 & 0.54 \\
Ahmadinejad & -0.83 & 0.84 & 0.23 & 0.77 \\
Meshal & -0.95 & 0.80 & 0.28 & 0.72 \\
\hline
\end{tabular}

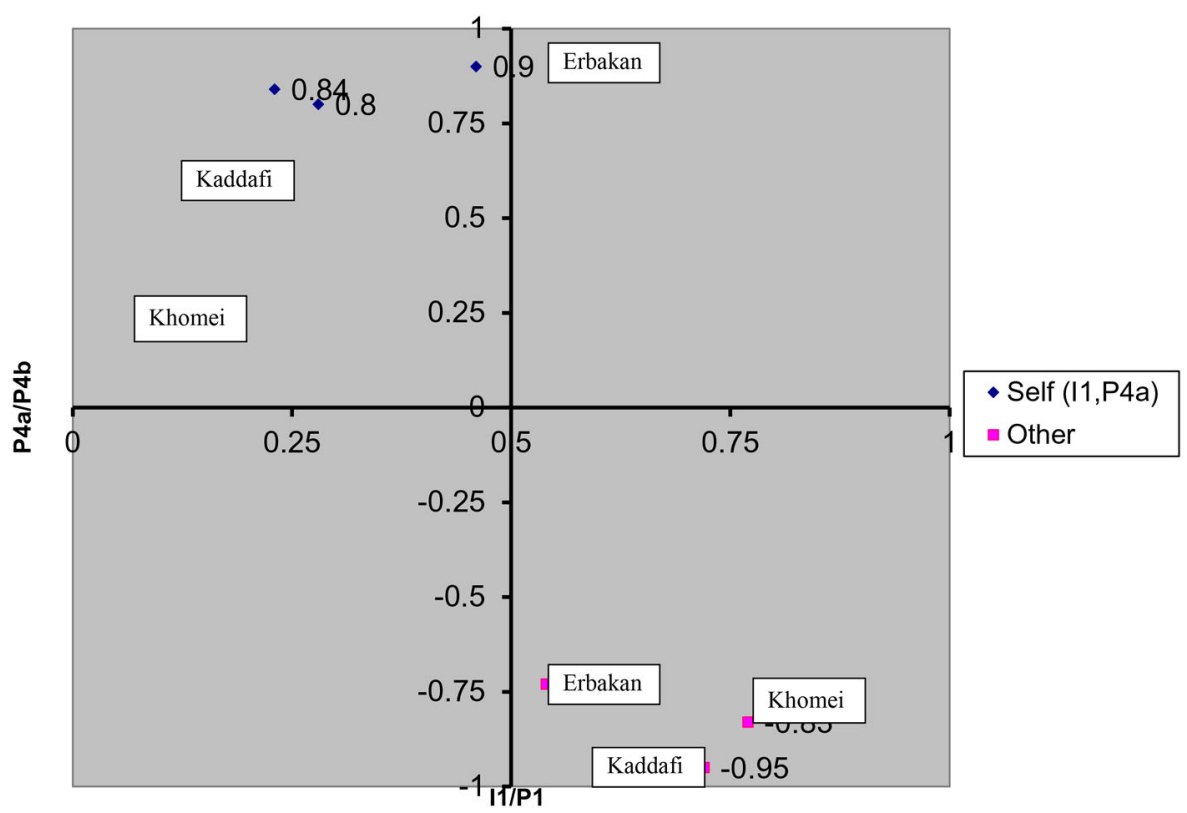

Figure 1. Three Original Islamist Leaders According to Their Leadership Type.

of historical control. Such leaders tend to exhibit choice and shift propensities that favour tactics of "appease" and "bluff", associated with an appeasement strategy ${ }^{59}$ (see also Table 1 for further explanation).

The operational code analyses of the three former Islamist leaders exhibit some further uniformity. Erbakan's, Qaddafi's and Khomeini's perception of the "other" is in quadrant B. That is, other leaders and the political world are sources of conflict, and historical control lies with the opponent. Type B leaders

59. Stephen G. Walker, "Forecasting the Political Behavior of Leaders with the Verbs in Context System of Operational Code Analysis", Research Report (2000). 


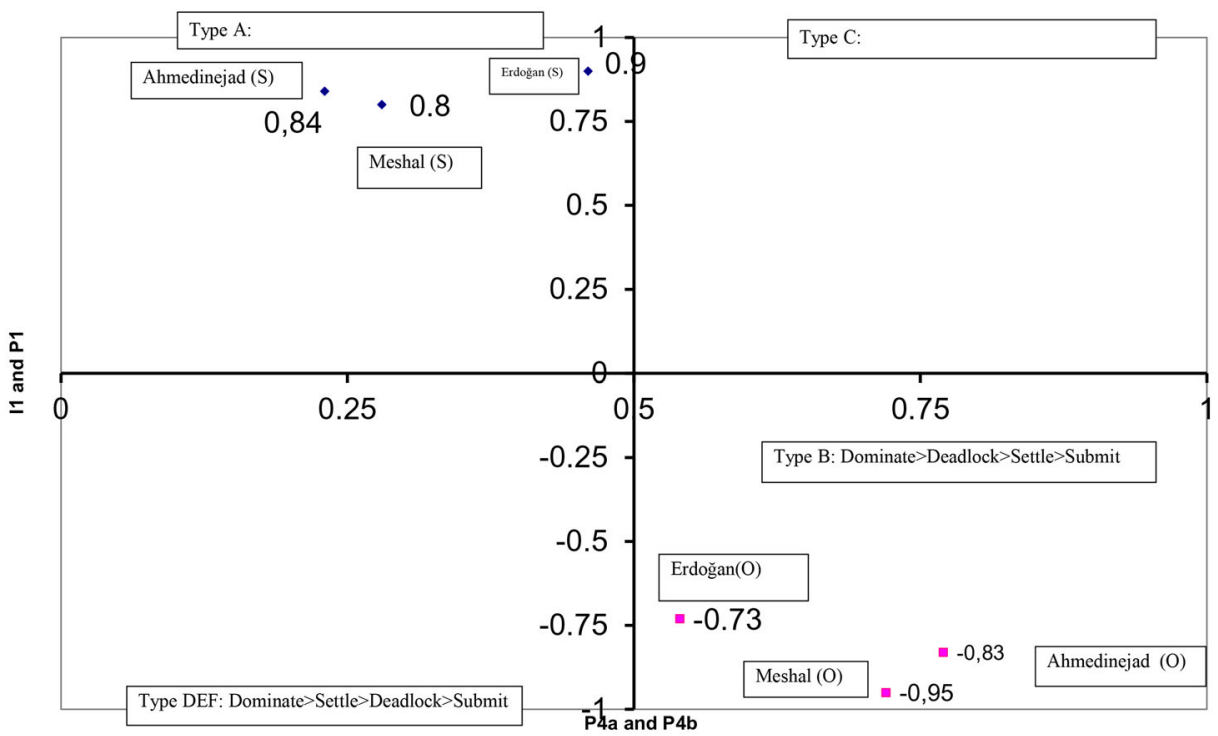

Figure 2. The Neo-Islamist Leaders According to Their Leadership Type.

exhibit a relatively hostile strategic orientation and a high sense of historical control. They are likely to favour tactics of "bully" and "exploit", associated with a brinkmanship strategy. ${ }^{60}$ Considering the background of Islamism as a reaction to colonialism and Western penetration into the region, these results show the validity of the coding because they represent high levels of distrust and "fear" of others.

The neo-Islamist leaders' operational codes also feature similarities, as Table 5 and Figure 2 show. My analysis of Erdoğan's speeches reveals results that are both consistent with and challenges for conventional images of Islamists. According to the analysis, Erdoğan believes that the political universe is very hostile and that he has medium control over historical developments. According to Erdoğan's operational code, others in the political universe pursue a relatively hostile strategic orientation and have more historical control over events (Type B). They likely favour a brinkmanship strategy. ${ }^{61}$ Erdoğan's conceptualisation of himself is in quadrant A. He pursues shared interests by following flexible strategies and shuns brinkmanship as much as possible. According to Walker, Type A leaders pursue a relatively friendly strategic orientation but feel that they have relatively less historical control over events. These leaders presumably exhibit choice and shift propensities. ${ }^{62}$

Ahmadinejad's speeches also reflect a conflictual worldview. He perceives historical control as belonging with the other. This propensity appears to be a typical feature of Iranian politicians, given their historical problems with foreign powers. Ahmadinejad also sees himself as very cooperative. Meshal appears to have the most negative worldview. His P-1 (sense of the political universe as conflictual or cooperative) score is almost as conflictual as it can get. Given the status of

60. Ibid.

61. Ibid.

62. Ibid. 
the Palestinian Authority and its relations with Israel and the rest of the world, this perception is understandable. Meshal also seems to be pro-cooperation regarding his in-group, and his low level of historical control is in line with political Islamists' worldviews and belief systems. Both Ahmadinejad's and Meshal's self-perceptions are Type A while they perceive the other as Type B.

My analysis of the philosophical and instrumental beliefs of the three original Islamist leaders reveals some patterns in how political Islam as an ideology appeared and articulated itself. The most general theme in these leaders' speeches is an anti-West sentiment. For Qaddafi, this was reflected most frequently as anticolonialism because of Libya's experience as a colony; for Khomeini, it manifested as anti-imperialism because of how Iran was pushed and pulled by the great powers of the 19th and 20th centuries; and for Erbakan, it was revealed as antiinternational capitalism, perhaps due to Turkey's economic decline during the 18th and 19th centuries and its reduction to small power status by Britain and France after World War I. The original three Islamist leaders were very critical of all forms of Western penetration into the region. Their criticism and high levels of distrust of the West ${ }^{63}$ are confirmed by the operational code approach. All three leaders exhibited very negative and high P-1 scores.

Such a historical background also contributes to these leaders' uniform perceptions of historical control lying more with the "other" than the self, as P-4a (sense of mastery or control) scores suggest. Colonisation, imperialism and great power penetration into their countries and the region, as well as the gradual weakening and final destruction of the Ottomans by Western powers, diminished regional leaders' self-confidence in general. Specifically, due to their ideology and how they analyse the region's history, Islamist leaders are not fully confident about historical control compared with Western leaders whom operational code researchers have analysed. ${ }^{64}$ In all speeches and articles coded, there is an extremely high level of historical control attributed to others. Political Islamists mostly do not attribute social, political and economic changes to domestic factors. The high scores of $\mathrm{P}-4 \mathrm{~b}$ and low scores of $\mathrm{P}-4 \mathrm{a},{ }^{65}$ mentioned above, are the patterns detected in political Islamists' operational codes in addition to similar P-1 (political universe as cooperative or conflictual) and I-1 scores (which represents instrumental beliefs of a leader in terms of cooperation and conflict).

Finally, in terms of the strategies employed, the "original" political Islamists present a mixed picture. In the most general pattern, they see themselves as cooperative if opportunities arise. Towards their in-group, all six leaders seem cooperative. However, how the in-group is defined varies from one Islamist to another. While some Islamist leaders (such as Erbakan, Erdoğan and Ahmadinejad) perceive all Muslims as their in-group, the in-groups of some other leaders have been very small, such as Khomeini's in-group which included only Shia clergy and oppressed Palestinian Muslims. The new Islamists show similar categorical beliefs to each other in terms of the P-1, P-4 and I-1 constructs.

63. Black, op. cit.

64. For example, Jimmy Carter's P-4 score was 0.65 during 1977 to 1979 (Walker, Schafer and Young, op. cit.); or Margaret Thatcher's varied in her tenure depending on the issue between 0.58 and 0.73 (Crichlow, op. cit.). The Islamist leaders' P-4 varied from 0.23 to 0.46 .

65. P-4 (mastery or control of history) is calculated as P-4b $=1-\mathrm{P}-4 \mathrm{a}$. Therefore, low scores of P-4a (self's mastery) mean higher scores of P-4b (other's mastery). 
This consistency in scores over time periods and between leaders seems to confirm that political Islam as a distinct political ideology seems to have a rather unified worldview about international affairs. On the other hand, my expectations of more significant differences existing between former and current Islamist leaders was not supported in this preliminary analysis. Only Erdoğan's historical control $(\mathrm{P}-4 \mathrm{a})$ is significantly higher than that of the other Islamist leaders; he is also generally friendlier towards others, including the West. This analysis shows general patterns of beliefs about foreign policy among Islamist leaders. The operational codes of the second three representative Islamist leaders show similar approaches to foreign policy, despite their different personal and country-specific backgrounds. It appears that operational code analysis is a theoretically robust construct that can be applied to other political units, regions and cultures. However, methodologically, researchers must be very careful about the effects of culture and geography on results. The boundaries of operational code research methodology may not be extended to other cultures and regions easily, which is the topic of the next section.

\section{Theoretical and Methodological Issues Concerning the Use of Operational Code Analysis to Analyse Middle Eastern and North African Islamist Leaders}

\section{Theoretical Issues}

Using the operational code construct to analyse Islamist leaders in the MENA has theoretical justifications. To begin with, the construct is one of the most theoretically developed leadership analysis tools in the literature. It has been applied to more than 30 world leaders, with many essays on the subject published in respected scientific journals. Therefore, it has a proven record of prediction and explanation. The researcher can resort to many different studies and learn from other researchers' experiences. Furthermore, operational code analysis was developed to analyse a group of political decision-makers' belief systems with the aim of determining patterns and making behavioural predictions; this is exactly the aim of my research on political Islamists. In short, the level of theoretical development of operational code analyses is one of the major reasons I chose the operational code construct to analyse MENA leaders.

Using the operational code construct in a new context has been discussed previously in the literature. For example, Alexander George ${ }^{66}$ simplified and theoretically codified the operational code construct for the aim of applying it to other polities than the USSR.

I have tried in this paper to codify the general issues and questions around which such a belief system is structured in the hope that it will encourage and facilitate systematic efforts to apply this research approach to a variety of other ruling groups and individual political leaders as well. The possibility emerges of a useful new dimension for comparative studies of different leaders and elite groups. ${ }^{67}$

66. Alexander L. George, The "Operational Code": A Neglected Approach to the Study of Political Leaders and Decision-Making (Santa Monica, CA: RAND Corporation, 1967), available: <http://www.rand.org/ pubs/research_memoranda/RM5427.html>, also available in print form: George, "The Operational Code", op. cit.

67. Ibid., p. 220. 
George also takes up this challenge in the article by introducing brief analyses of cases from American foreign policy while discussing the operational code construct.

Stephen Walker also discussed the applicability of the operational code construct in a comparative manner. ${ }^{68}$ Walker, when discussing the flourishing of the operational code literature after George's seminal article in 1969, suggests that the following two decades witnessed many US scholars using the construct to analyse various American decision-makers. Walker discusses the difficulties associated with converting the operational code construct from the Soviet focus to US decision-makers. ${ }^{69}$ He suggests that only some research has successfully made the theoretically consistent link between US leaders' operational code and their perception of the Soviet Union by using both quantitative operational code analysis and process tracing techniques. In a later article in which Walker applies Lakatosian criteria of scientific progress to the research programme, he proposes a cautionary optimism about the success of operational code analysis in terms of scientific progress. ${ }^{70}$ Although overwhelming evidence suggests that "beliefs matter" in general, the operational code construct can only be said to show scientific progress if one can prove that beliefs do not fall into the endogeneity trap, i.e. they are independent from the structure's effects. For example, when tested against evidence (by analysing many different leaders from many different countries), the operational code construct can account for why European leaders gave completely different responses to Germany before 1914 and 1939 despite structural variables being quite similar. The answer is the differences in personal beliefs and the agent's interpretation of the structure, which the operational code construct can account for.

Operational code analysis also fits well with the nature of the data on MENA leaders. In many countries, the quality of bureaucracy is rather low, with, for example, few services for recording, archiving and publishing leaders' speeches. This may be because such countries come from a so-called "oral tradition", where state records, speeches and even literary works are less often and less professionally recorded. Furthermore, MENA countries have scant academic literature and no journalistic tradition of psycho-biographies. For these reasons, using a leader's available speeches for analysis at a distance is the best choice.

The main problem I encountered during my research was a classic "level of analysis" problem; in this case, single-leader analysis versus an (elite) group-ofdecision-makers analysis. Operational code analysis can be applied to leaders as well as groups. In some cases, leader-focused analysis is illuminating in terms of examining a country's foreign policy behaviour. If a country (such as the United States) has a presidential system, or a strong leader is in power, leader-focused analysis is perhaps more appropriate. In other polities, analysing a certain group's impact on foreign policy decisions is more important. In such cases, the administrative and political systems of the country assign a greater role to groups rather than single leaders. Therefore, while conducting the analysis I

68. Walker, "The Evolution of Operational Code Analysis", op. cit.; Walker, Forecasting the Political Behavior, op. cit.

69. Walker, "The Evolution of Operational Code Analysis", op. cit., p. 414.

70. Stephen G. Walker, “Operational Code Analysis as a Scientific Research Program: A Cautionary Tale", in Colin Elman and Miriam Fendius Elman (eds.), Progress in International Relations Theory (London: MIT Press, 1998), pp. 245-276. 
realised that the predictions one can make from operational code analysis must be reviewed cautiously. If a country's foreign policy decision-making system is very complicated (as is Iran's), predicting that country's foreign policy decisions on the basis of operational code analysis should perhaps be undertaken more cautiously. For example, group analysis would be more relevant for Hamas because its structure is not as homogenous as an organised Western political unit, such as a cabinet. The foreign policy behaviour of the group is shaped by different units, such as sub-groups or individuals. That said, I did not have a major problem with the unit of analysis because my aim was to analyse different leaders from a certain political ideology and make inferences about that ideology. However, if one wanted to predict Iranian foreign policy behaviour, one would have to be more careful not to over-generalise the results.

Furthermore, during the research, I realised that mere operational code analysis may not prove sufficient to predict a country's foreign policy behaviour at every decision point. Depending on the system, constitutional rules and the decision itself, different decision units may be more important. ${ }^{71}$ In Turkey, for example, in most cases the foreign policy decision unit is the cabinet, which usually follows the prime minister's choices. However, the Turkish constitution requires a parliamentary decision to go to war and to admit foreign troops into the country. This difference explains why, although Erdoğan was in favour of joining the Iraq War in 2003, the Turkish parliament rejected that policy and did not admit US troops into Turkey. ${ }^{72}$

Another theoretical issue about the boundedness of operational code analysis regards contextual or temporal limitations. In many cases in the MENA, it is likely that a state's foreign policy agenda is dominated by a specific problem. Thus, the leader's foreign policy belief system is shaped by the set of specific and paramount events of that period. In such cases, it becomes difficult to determine the leader's general foreign policy orientation. ${ }^{73}$ For example, the Kurdistan Workers' Party (PKK) issue continues to dominate the Turkish foreign policy agenda and therefore the content of Turkish leaders' foreign policy speeches. ${ }^{74}$ In such cases, the narrow focus on foreign policy speeches leads to distorted operational code results in terms of explaining the perception of the leaders and general foreign policy tendencies of these countries. Likewise, I faced similar problems when analysing Hamas leaders' operational codes. The conflict with Israel and the Israeli occupation of Palestinian territories constitute the most vital items in Hamas's foreign policy agenda. Therefore, the salience of the conflict between the Israeli and Palestinian parties makes it extremely difficult to differentiate between the operational code of the Hamas leadership on general foreign affairs and between Israel and the status of Palestine. This requires finding different sources of speeches and articles and examining them carefully.

71. Margaret G. Hermann, "How Decision Units Shape Foreign Policy: A Theoretical Framework", International Studies Review, Vol. 3, No. 2 (2001), pp. 47-81.

72. Zeynep Taydaş and Özgür Özdamar, "A Divided Government, an Ideological Parliament, and an Insecure Leader: Turkey's Indecision about Joining the Iraq War", Social Science Quarterly, Vol. 94 , No. 1 (2013), pp. 217-241.

73. There is a debate about whether leaders have a general operational code or whether there are separate operational codes for different issues of foreign policy (Walker, Schafer and Young, op. cit.).

74. The PKK is an armed militia group that has fought against Turkish governments since 1984 to secede south-east Turkey in order to establish an independent Kurdish state. The PKK is on the list of terrorist organisations for Turkey, the EU and the United States. 
Operational code analysis can result in several insights and the ability to elicit general predictions about the decision-making unit under discussion. Yet these results remain too abstract when not evaluated within a broader research agenda. Operational code findings must be incorporated into different literatures such as game theory and/or leadership trait analysis. The preference order of a leader found by operational code analysis can be an effective starting point for establishing a game in which the leader's preferences can be plugged into a game theoretical model that focuses on a particular foreign policy decision. ${ }^{75}$ The leadership typology literature is also an appropriate sphere in which to evaluate the operational code of the leader in terms of locating him or her within a specific typological model. ${ }^{76}$

However, the problem with these cross-theoretical endeavours is that they require additional training. Considering the modest methodology course requirements in PhD programmes throughout the world, except for the United States, it becomes difficult to co-author with other scholars or even one's own graduate students. Therefore, the theoretical richness and eclecticism of operational code research becomes an obstacle even to itself. Many researchers are cautious about learning to undertake this analysis because they feel they cannot publish their results without using additional tools and literatures. Learning operational code analysis requires a significant investment of time and energy, and theoretical and methodological eclecticism works against drafting more analysts into the discipline.

\section{Procedural and Methodological Problems}

Perhaps the most pressing issue with the operational code construct is related to languages. When coding Turkish texts and texts translated into Turkish from Arabic and Farsi, it was obvious that the logic of operational code analysis is based exclusively on English. Sentences in English texts are usually relatively short, sentence structures are straightforward, and use of the passive voice is minimal. This kind of simple yet efficient writing seems exclusive to English; French and German political and academic literatures seem unnecessarily complicated. The situation is similar for Turkish, Farsi and Arabic.

Middle Eastern languages are ancient and rich in their expressions. Because speeches are generally designed for leaders to outsmart their political rivals by appearing cleverer and wittier, they are very difficult to decompose and code according to operational code rules. For example, in political speeches intended to excite public rallies, there are countless sentences without a verb. These sentences are nonetheless very strong politically and exhibit negative attitudes towards foreign powers or domestic political rivals. At this point, the researcher faces a dilemma: whether to code this obviously negative attribute against the political other or abide by the operational code protocol and exclude any sentence without a verb (or transitive verb). In my research, I tried to do the former. I relaxed the coding rules in favour of non-transitive verbs and designed a new and consistent protocol to code Turkish and texts translated from Arabic

75. Walker, Forecasting the Political Behavior, op. cit.

76. Jerrold M. Post (ed.), The Psychological Assessment of Political Leaders. With Profiles of Saddam Hussein and Bill Clinton (Ann Arbor, MI: University of Michigan Press, 2005). 
and Farsi into Turkish. In the end, our coding-i.e. that of the principal researcher and two research assistants-showed very high levels of intercoder reliability.

Coding transitive verbs exhibits a similar problem. ${ }^{77}$ In English and non-English speeches, transitive verbs are coded as reflections of negative or positive attributions to self and other. Yet it does not suffice to code negative and positive attributions associated with a verb only; sometimes the context of the sentence implies a clear negative attribution even though the sentence does not include a transitive verb (as in the verb-less sentences discussed above). For example, Necmettin Erbakan said: "They [Americans] are the greatest pharaohs to the Muslim people". According to the original operational code protocol, this sentence has no coding value. However, in hand coding, if one understands the political ideology of the owner of this sentence, the culture of the country, the biblical reference to pharaohs and its meaning for political Islamists today, one would know this sentence means: "Americans oppressed (or persecuted) the Muslim people more than anybody else did".

Decomposing and rewriting the sentence as such, the researcher can code it as "Other-Negative" and not miss such a clear and strong negative attribution to other. Automated systems are not capable of doing this. There are also other types of verbs in other languages that can refer to deeds and actions but that do not exist in English (for example, işteşfiller - widely used in Turkish - is roughly the same as reciprocal verbs in English, where the verb refers equally to two subjects, e.g., as in "exchange" and "marry"). In Turkish, these verbs may also refer to strong political actions (negative or positive) that should be included in the coding. For these reasons, I believe that hand coding may be a better option for analysing speeches in different political contexts and languages. I also maintain that rich examples of adjectives or adjectives used as verbs should also be examined for attributions of self and other. Furthermore, the researcher must decide how or whether to code rich sets of expressions, proverbs, aphorisms, idioms and adjectives that politicians speaking in MENA languages frequently use.

For at least two reasons, hand coding is also better at differentiating between a politician's in-group and out-group. First, in automated systems, the computer codes according to "I" and "we". In the political culture of the Middle East, "I" and "we" are often reversed. Like the "royal we" in English, politicians like to use "we" when they mean "I". Culturally, the idea is to appear more humble by not using the "I", but it leads to some confusion for the researcher. Second, leaders' in-groups and out-groups can be completely different even if they hail from the same ideology; automated systems' focus on pronouns may not give the same results as hand coding. For example, for Erbakan all Muslims were his in-group and therefore his approach was very cooperative. Khomeini's in-group was much smaller, however; to him, the only groups that deserved his cooperation were the Shia clerics and some oppressed Muslim communities, such as Palestinians. I believe that hand coding is the best tool to capture these differences and

77. Another smaller problem is the minimum number of verbs necessary to code. The general principle in operational code analysis is to code all speeches that include at least 20 transitive verbs. Having such a threshold was sometimes not practical. Although the number of verbs was low in some speeches, they nonetheless included strong and determinant attributions that reflected its general theme. Perhaps it is best to let the hand coder determine the eligibility of such speeches on an individual basis. 
thus improve the coding's validity. If, for example, a leader's mind is not as transparent as an American president's, the traditional operational code rules do not apply. If one is coding a speech from Richard Nixon or Lyndon B. Johnson during the height of the Cold War, "I", "we" and "us" are rather easy to determine: meaning themselves, the West, NATO and/or American allies. But for Khomeini, the West was not the only enemy; Muslims who envied the West, Muslims who allied with the United States, and Sunnis in general also belonged to the out-group.

\section{Problems Related to MENA Politics}

The most specific problem in applying operational code analysis to MENA leaders is that political Islam as a movement is diverse and non-bounded. When I began this research, I had the following problem in mind: Leites had used operational code to analyse a narrow group of people. The smaller group size (elite Bolsheviks), its unified ideology (Leninism), specific institutional structures (decisions made by the Politburo) and the members' cultural and linguistic similarities (all Soviet citizens speaking Russian) rendered his analysis capable of making rather sound generalisations. $^{78}$

For political Islamists, except for the Quran and the Sunna, the ideological sources they read are much more diverse than the Politburo members' sources were. The sources of Islamist leaders' issues and the political influences on them are also more diverse. For example, Khomeini's political views were strictly based on Shia readings and theological ideas about the Twelve Imam traditions of Shiism. Erbakan, on the other hand, seemed to have been affected by Sunna insights (deeds of the Prophet Mohammed) and some Turkish and Kurdish religious scholars such as Said Nursi or those of the Naksebendi order. Given the region's diversity of religious sects and beliefs, countries' historical experiences and the various religious and philosophical references, I questioned whether I could generalise about a set of leaders. However, when the results showed great consistency, operational code analysis seemed a good choice for analysing even such a diverse group.

As noted earlier, data availability was a major problem. Specifically, speeches by Qaddafi were difficult to find due to political reasons (authoritarianism in the country and Libyan foreign service employees' fear of possible consequences if they gave me access to speeches). Due to its loose institutional structure and its above-discussed focus on one foreign affairs issue, it was also difficult to access data that reflected Meshal's foreign policy beliefs. In more developed systems, it was much easier to access sources; one can easily download Erdoğan's many speeches from the AKP's website.

78. Using the operational code construct in a similar fashion to Leites' handling of the Bolshevik party raises a question about whether Bolsheviks and Islamists share similar approaches to politics. The answer is mixed. Bolsheviks' ideology is associated with economic planning, communist state and society, atheism, one-party state and proletariat dictatorship and vanguardism, which are incompatible with Islamist ideology. By definition, Islamists are not atheists and they do not presume a utopian egalitarian society. However, there are some interesting similarities between the two ideologies. Both ideologies claim to be anti-imperialistic, and their discourse is generally anti-West for different reasons. They are both utopian in terms of the state and society they aspire to reach; in Islam this is a state represented by Prophet Mohammed's brief tenure as a ruler of the first Muslim tribes in the 7th century whereas Bolshevik ideology envisioned a stateless communistic society. Finally, both ideologies are cosmopolitan in nature and claim to have transnational appeal that goes beyond borders. 
Moreover, a general problem in operational code research with specific reference to MENA is whether the operational code approach's assumptions that courses of actions and leader accountability are adequately reflected in leaders' operational codes are correct. Operational code research assumes that leaders' speeches reflect their belief systems; thus, one can predict their foreign policy behaviour. The operational code analysis literature also assumes a principle of accountability, which means that leaders' actions are limited by what they say in their public speeches. This situation may be more the case in developed democracies, such as the United States, where political accountability is expected from leaders. In such countries, leaders are held accountable for consistency between their speeches and actual foreign policy decisions. On the other hand, in the MENA, the principle of accountability is often lacking. Leaders may exhibit different foreign policy behaviour than suggested from their public speeches. In autocratic regimes especially, leaders are much less accountable in all policy areas, including foreign policy.

There is also inconsistency between speeches and acts in domestic and foreign speeches. For example, I realised that the tone of leaders' speeches changes from audience to audience and subject to subject. Qaddafi seemed less aggressive talking to French journalists than to the Libyan youth at home. When acting on international platforms, such as the United Nations, the leaders' speeches seem more "balanced" than their campaign speeches. For these reasons, the operational code rule that speeches must be about the same subject and addressed to similar audiences must be implemented. We should be collecting as many speeches as possible to prevent data distortion when analysing domestic and international speeches.

The last regional difficulty involves the MENA's lack of developed university systems, scientific production and theoretical foreign policy analysis research. There are few scholars-outside of North America-who focus on theoretical approaches coming from the periphery, the non-Western international relations (IR) community's sociology, or scientific, quantitative studies of middle or smaller powers' foreign policies. ${ }^{79}$ The dearth of such resources meant that there was little or no literature to resort to when encountering problems. Scientific experience means learning from other researchers' experiences, insights and mistakes. Yet, since there are not many FPA studies from the regional universities or focusing on the MENA, I lacked resources to consult when facing a problem.

\section{Conclusion}

A general evaluation of the above discussion suggests that the operational code research agenda has great scientific value and is capable of producing insights

79. See Ali Karaosmanoğlu and Ersel Aydınlı, "Launching All Azimuth", All Azimuth, Vol. 1, No. 1 (2012), pp. 5-7 for an elaboration of the Western orientation of IR theories and the need to give voice to alternatives from the periphery; Seçkin Köstem, "International Relations Theories and Turkish International Relations: Observations Based on a Book", All Azimuth, Vol. 4, No. 1 (2015), pp. 59-67 for the Turkish IR community's sociological analysis; Hong-Cheol Kim and Patrick James, "The Paradox of Power Asymmetry: When and Why Do Weaker States Challenge US Hegemony?", All Azimuth, Vol. 5, No. 2 (2016), pp. 5-28 for a quantitative analysis of small state foreign policy; and Musa Tüzüner and Gonca Biltekin, "A Pilot Study of Quantifying Turkey's Foreign Affairs: Data Generation, Challenges and Preliminary Analysis", All Azimuth, Vol. 2, No. 2-SI (2013), pp. 45-70 for an analysis of Turkish foreign policy as a middle power. 
when applied even to regions and political cultures that are very different from the United States. I believe the operational code construct is universally applicable because its foundational principles are based on universal psychological assumptions. The success of operational code research reflects the success of cognitively oriented research paradigms in general. The operational code construct, as a via media position in the FPA field, i.e. the combination of competing cognitive research and game theoretic models, is also appreciated. ${ }^{80}$ By including both competing paradigms in FPA, the operational code construct has gained insight and rigour.

However, applying the operational code's procedural and methodological assumptions to non-Western groups or leaders must be carefully reconsidered. The experience from the MENA shows mixed results. Although I argue that the basic logic of operational code research is valid for Middle Eastern and North African political systems and leaders (and perhaps for all regions), details about how to produce operational code scores for leaders may need to be tailored according to the language used, characteristics of the political system, and the country. Above all, the coding rules designed for the English language may not prove valid when applied to other languages. The fine details, nuances and idiosyncrasies of a certain language must be considered, and coding flexibility to overcome these difficulties should be tolerated by the operational code research community in general. In some regions and cultures, such as the MENA, I suggest employing hand coding rather than running translated English speeches through automated coding.

Adapting North American FPA theories to other cultural settings will benefit the theory itself, the FPA field in general, and research and scientific development about the country in question, as well as produce cumulative knowledge. As it is applied to different leaders from different polities, operational code research will be enriched. It will expand and become methodologically more diverse and eclectic, thus producing a more comprehensive body of knowledge. Such research will consolidate FPA's position as a subfield of IR, or as "the ground of IR", as Valerie Hudson suggests. ${ }^{81}$ FPA has the potential to serve as a bridge between theory and practice, the abstract and the applicable, science and policy, the material and the ideational. ${ }^{82}$ Theoretically and methodologically, it holds a bridging position between the most abstract IR studies and the most practical ones. Expanding the scope of FPA to other regions, methods and theories will help to further consolidate its sound position in the discipline.

Such applications of FPA theories will also inspire researchers in developing countries. Small research communities in different regions can build on existing FPA theories and their nascent applications to their regions. These studies, in time, will help developing countries build their own literatures. Applying FPA theories to developing parts of the world may become one of the most exciting and fruitful endeavours in political science in the coming decades.

80. B. Gregory Marfleet and Colleen Miller, "Failure after 1441: Bush and Chirac in the UN Security Council", Foreign Policy Analysis, Vol. 1, No. 3 (2005), pp. 333-360; Akan Malici, "Reagan and Gorbachev: Altercasting at the End of the Cold War", in Schafer and Walker, op. cit., pp. 127-150; Huiyun Feng, op. cit.

81. Valerie M. Hudson, "Foreign Policy Analysis: Actor-Specific Theory and the Ground of International Relations", Foreign Policy Analysis, Vol. 1, No. 1 (2005), pp. 1-30.

82. Alexander L. George, Bridging the Gap: Theory and Practice in Foreign Policy (Washington, DC: United States Institute of Peace, 1993). 


\section{Acknowledgements}

I would like to thank Valerie Hudson, Klaus Brummer and anonymous reviewers for their valuable comments and Sercan Canbolat and Toygar Halistoprak for their research assistance in coding the relevant speeches.

\section{Disclosure statement}

No potential conflict of interest was reported by the author.

\section{About the Author}

Özgür Özdamar teaches at Bilkent University's Department of International Relations. He has taught at different institutions, such as the University of MissouriColumbia, Stephens College, Ministry of Foreign Affairs of Turkey, TOBB-ETÜ, the Turkish Military Academy and the National Security College. His research focuses on foreign policy analysis, forecasting, international relations theories and security studies. He currently serves as editor of All Azimuth: Journal of Foreign Policy and Peace and director of research at Center for Foreign Policy and Peace Studies.

\section{Appendix (Speeches and Tables)}

Islamists - List of All Speeches Coded

Ruhollah Khomeini

Khomeini, Ruhollah, "Israel: As the enemy of Muslims and Islam", available: <http://www.imam-khomeini.com> (accessed 28 February 2011).

Khomeini, Ruhollah, "The Granting of Capitulatory Rights to the U.S", Islam and Revolution (Trans. Hamid Algar, Mizan Press, CA: Berkeley, 1981), pp. 181-188.

Khomeini, Ruhollah, "Islamic Government", Islam and Revolution (Trans. Hamid Algar, Mizan Press, CA: Berkeley, 1981), pp. 27-39.

Khomeini, Ruhollah, "Address to Monsignor Bugnini, Papal Nuncio", Islam and Revolution (Trans. Hamid Algar, Mizan Press, CA: Berkeley, 1981), pp. 278-285.

Khomeini, Ruhollah, "Thirty Million People Have Stood Up", Islam and Revolution (Trans. Hamid Algar, Mizan Press, CA: Berkeley, 1981), pp. 321-329.

Khomeini, Ruhollah, "New Year's Message", Islam and Revolution (Trans. Hamid Algar, Mizan Press, CA: Berkeley, 1981), pp. 286-294.

Khomeini, Ruhollah, "Message to the Muslim Students in North America", Islam and Revolution (Trans. Hamid Algar, Mizan Press, CA: Berkeley, 1981), pp. 209-211.

Note: All speeches are in English. They were translated from Farsi by the publisher.

\section{Necmettin Erbakan}

Erbakan, Necmettin, "Our Industrial Cause and Zionist Obstacles", <http://www. necmettinerbakan.org> (accessed 28 February 2011). 
Erbakan, Necmettin, "International Relations and Foreign Policy" (26 April 1980), <http://www.necmettinerbakan.org> (accessed 28 February 2011).

Erbakan, Necmettin, “On the Priorities of Foreign Policy with Prof. Dr Necmettin Erbakan", Interview: Hasan Hüseyin Ceylan. Dış Politika, 3rd Issue. (October 1988)

Erbakan, Necmettin, "Gulf Crises”, Ankara Mülkiyeliler Birliği, 1990.

Erbakan, Necmettin, “The Common Market and Turkey”, Elazı̆̆ , 1987, <http:// www.necmettinerbakan.org> (accessed 28 February 2011).

Note: All speeches are in Turkish and original.

\section{Muammar Qaddafi}

Qaddafi, Muammar. “Exploitation”, My [Political] Views, Trans. Mehmet Keskin, Hareket Press, Istanbul, 1974, pp. 11-56.

Qaddafi, Muammar. "The Third Universal [State] Theory", My [Political] Views, Trans. Mehmet Keskin, Hareket Press, Istanbul, 1974, pp. 56-94.

Note: All speeches are in Turkish. They were translated from Arabic to Turkish by the publisher.

Islamists - Codings and Positive/Negative Attributions to Self/Other (Scores)

\begin{tabular}{llll}
\hline $\begin{array}{l}\text { Necmettin } \\
\text { Erbakan }\end{array}$ & & & \\
\hline Self & Negative & Positive & Sanayi Davamiz ve Siyonist Engelleri \\
Other & 27 & 34 & \\
& 17 & 6 & \\
& Negative & Positive & Uluslararasi İlişkiler Diş Politika (Meclis \\
S & 2 & 17 & Kürsüsünden) \\
O & 42 & 0 & \\
& & & \\
& Negative & Positive & Prof.Dr.Necmettin Erbakan ile Diş \\
S & 0 & 9 & Politika Öncelikleri Üzerine \\
O & 26 & 1 & \\
& & & \\
S & Negative & Positive & Mülkiyeliler Birliğinde \\
O & 1 & 26 & \\
& 70 & 6 & \\
S & Negative & Positive & Ortak Pazar ve Türkiye \\
O & 0 & 15 & \\
\hline
\end{tabular}




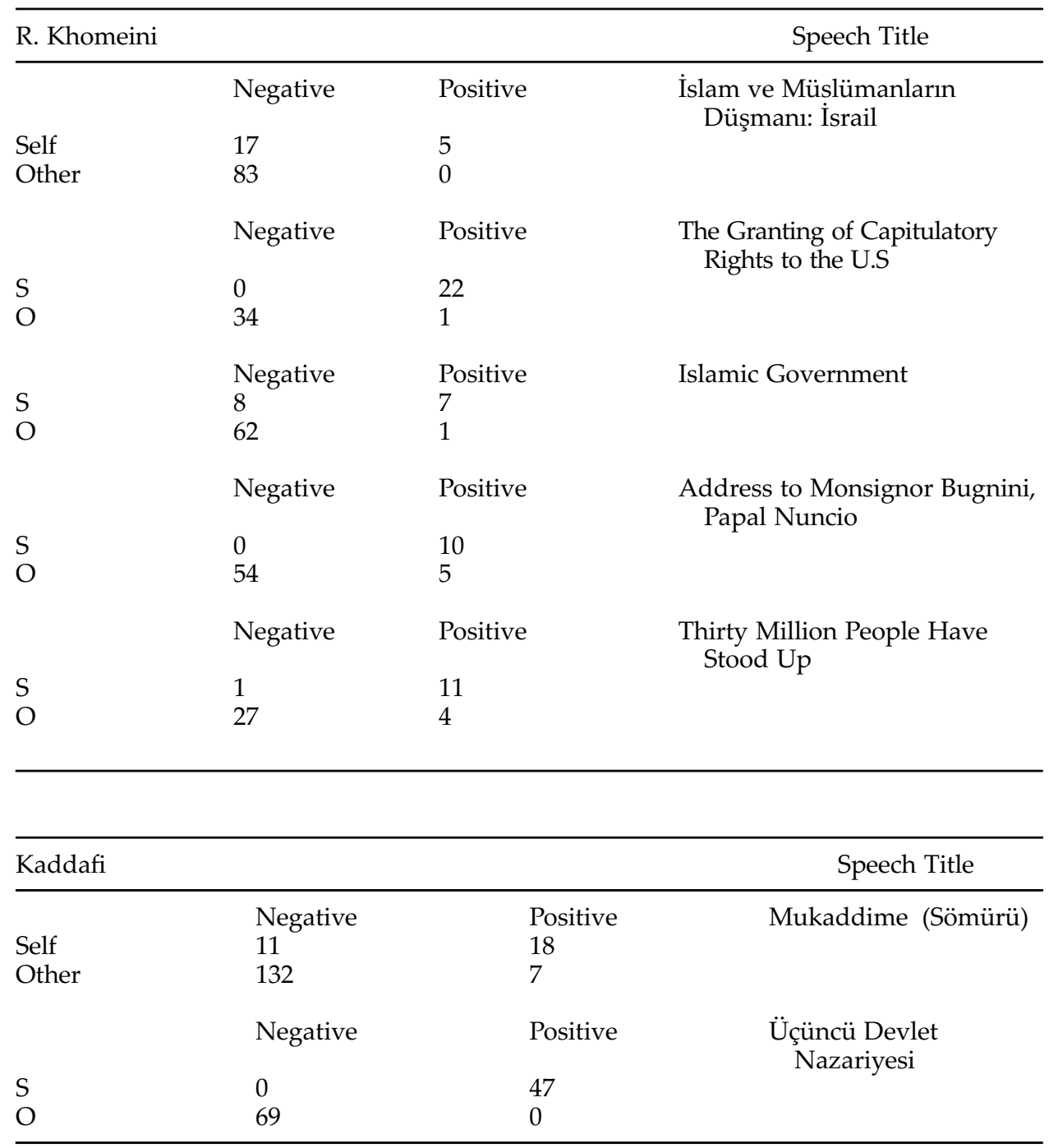

Neo Islamists - All Speeches Coded

Recep Tayyip Erdoğan

Erdogan T. Erdogan, "Erdogan's speech in AK party group meeting" (16 October 2007), available <http://www.akparti.org.tr/site/haberler/arsiv/tumu> (accessed 15 November 2011).

Erdogan T. Erdogan, "Erdogan's speech in AK party group meeting" (30 October 2007), available <http://www.akparti.org.tr/site/haberler/arsiv/tumu> (accessed 15 November 2011).

Erdogan T. Erdogan, "Interview with Erdogan in his US visit of 2007". Interview: 2007, available <http://www.akparti.org.tr/site/haberler/arsiv/tumu> (accessed 20 November 2011). 
Erdogan T. Erdogan, “Erdogan's speech in Turkish Parliament” (5 November 2007), available <http://www.akparti.org.tr/site/haberler/arsiv/tumu> (accessed 15 November 2011).

Erdogan T. Erdogan, "Joint Press Statement with Condoleezza Rice" (2 November 2008), available <http://www.akparti.org.tr/site/haberler/arsiv/tumu> (accessed 15 November 2011).

Erdogan T. Erdogan, "Interview with Erdogan in his visit to Romania in 2006", Interview: 2006. available <http://www.akparti.org.tr/site/haberler/arsiv/tumu> (accessed 15 November 2011).

Erdogan T. Erdogan, “Erdogan's speech in Turkish Parliament” (15 January 2008), available <http://www.akparti.org.tr/site/haberler/arsiv/tumu> (accessed 15 November 2011).

Erdogan T. Erdogan, "Erdogan's speech in AK party group meeting" (12 December 2006), available <http://www.akparti.org.tr/site/haberler/arsiv/tumu> (accessed 16 November 2011).

Erdogan T. Erdogan, "Erdogan's speech in AK party group meeting" (28 December 2006), available <http://www.akparti.org.tr/site/haberler/arsiv/tumu> (accessed 16 November 2011).

Erdogan T. Erdogan, "Erdogan's press conference in Turkish media"(10 October 2005), available <http://www.akparti.org.tr/site/haberler/arsiv/tumu> (accessed 16 November 2011).

Note: All speeches are in Turkish and original.

Mahmoud Ahmedinejad

Ahmadinejad, Mahmoud, "61st Session of the United Nations General Assembly" (September 2006).

Ahmadinejad, Mahmoud, "63rd Session of the United Nations General Assembly" (September 2008).

Ahmadinejad, Mahmoud, "65th Session of the United Nations General Assembly" (September 2010).

Ahmadinejad, Mahmoud, "Spiegel Interview with Iranian President Ahmadinejad" (October 2009).

Ahmadinejad, Mahmoud, “Time's Interview with Iranian President Mahmoud Ahmedinejad" (September 2009).

Ahmadinejad, Mahmoud, "Transcript of the Ahmadinejad Interview by Washington Post" (September 13).

Ahmadinejad, Mahmoud, "66th Session of the United Nations General Assembly" (September 2011).

Note: All speeches are in English. They were translated from Farsi. 
Neo Islamists - Codings and Positive/Negative Attributions to Self/Other (Scores)

\begin{tabular}{|c|c|c|c|}
\hline \multirow[t]{2}{*}{ R. Tayyip Erdogan } & \multirow[b]{2}{*}{ Negative } & & \multirow{2}{*}{$\begin{array}{c}\text { Speech Date/Title } \\
16 \text { October } 2007, \mathrm{AKP} \\
\text { party group meeting }\end{array}$} \\
\hline & & Positive & \\
\hline Self & 0 & 15 & \\
\hline Other & 17 & 8 & \\
\hline & Negative & Positive & $\begin{array}{l}30 \text { October } 2007, \mathrm{AKP} \\
\text { party group meeting }\end{array}$ \\
\hline S & 2 & 36 & \\
\hline $\mathrm{O}$ & 22 & 1 & \\
\hline & Negative & Positive & $\begin{array}{l}\text { Erdogan's Press } \\
\text { Conference in US, } 2007\end{array}$ \\
\hline S & 0 & 13 & \\
\hline $\mathrm{O}$ & 17 & 6 & \\
\hline & Negative & Positive & $\begin{array}{l}5 \text { November } 2007 \text { in } \\
\text { TBMM }\end{array}$ \\
\hline $\begin{array}{l}S \\
\mathrm{O}\end{array}$ & $\begin{array}{l}0 \\
7\end{array}$ & $\begin{array}{l}11 \\
3\end{array}$ & \\
\hline & Negative & Positive & $\begin{array}{l}\text { Joint Conference with } \\
\text { C. Rice }\end{array}$ \\
\hline $\begin{array}{l}\mathrm{S} \\
\mathrm{O}\end{array}$ & 0 & 9 & \\
\hline $\mathrm{O}$ & 8 & 3 & \\
\hline & Negative & Positive & $\begin{array}{l}\text { Interview with Erdogan in } \\
\text { Romania, } 2006\end{array}$ \\
\hline $\begin{array}{l}S \\
O\end{array}$ & $\begin{array}{l}2 \\
13\end{array}$ & $\begin{array}{l}11 \\
0\end{array}$ & \\
\hline $\begin{array}{l}\mathrm{S} \\
\mathrm{O}\end{array}$ & $\begin{array}{l}\text { Negative } \\
0 \\
11\end{array}$ & $\begin{array}{l}\text { Positive } \\
14 \\
0\end{array}$ & 15 January 2008 in TBMM \\
\hline & Negative & Positive & $\begin{array}{l}12 \text { December } 2006, \mathrm{AKP} \\
\text { party group meeting }\end{array}$ \\
\hline $\begin{array}{l}\mathrm{S} \\
\mathrm{O}\end{array}$ & $\begin{array}{l}1 \\
24\end{array}$ & $\begin{array}{l}21 \\
2\end{array}$ & \\
\hline & Negative & Positive & $\begin{array}{l}28 \text { November 2006, AKP } \\
\text { party group meeting }\end{array}$ \\
\hline $\begin{array}{l}\mathrm{S} \\
\mathrm{O}\end{array}$ & $\begin{array}{l}1 \\
23\end{array}$ & $\begin{array}{l}17 \\
3\end{array}$ & \\
\hline & Negative & Positive & $\begin{array}{l}\text { Press Conference, } 10 \\
\text { October } 2005\end{array}$ \\
\hline $\begin{array}{l}\mathrm{S} \\
\mathrm{O}\end{array}$ & $\begin{array}{l}2 \\
20\end{array}$ & $\begin{array}{l}15 \\
4\end{array}$ & \\
\hline
\end{tabular}




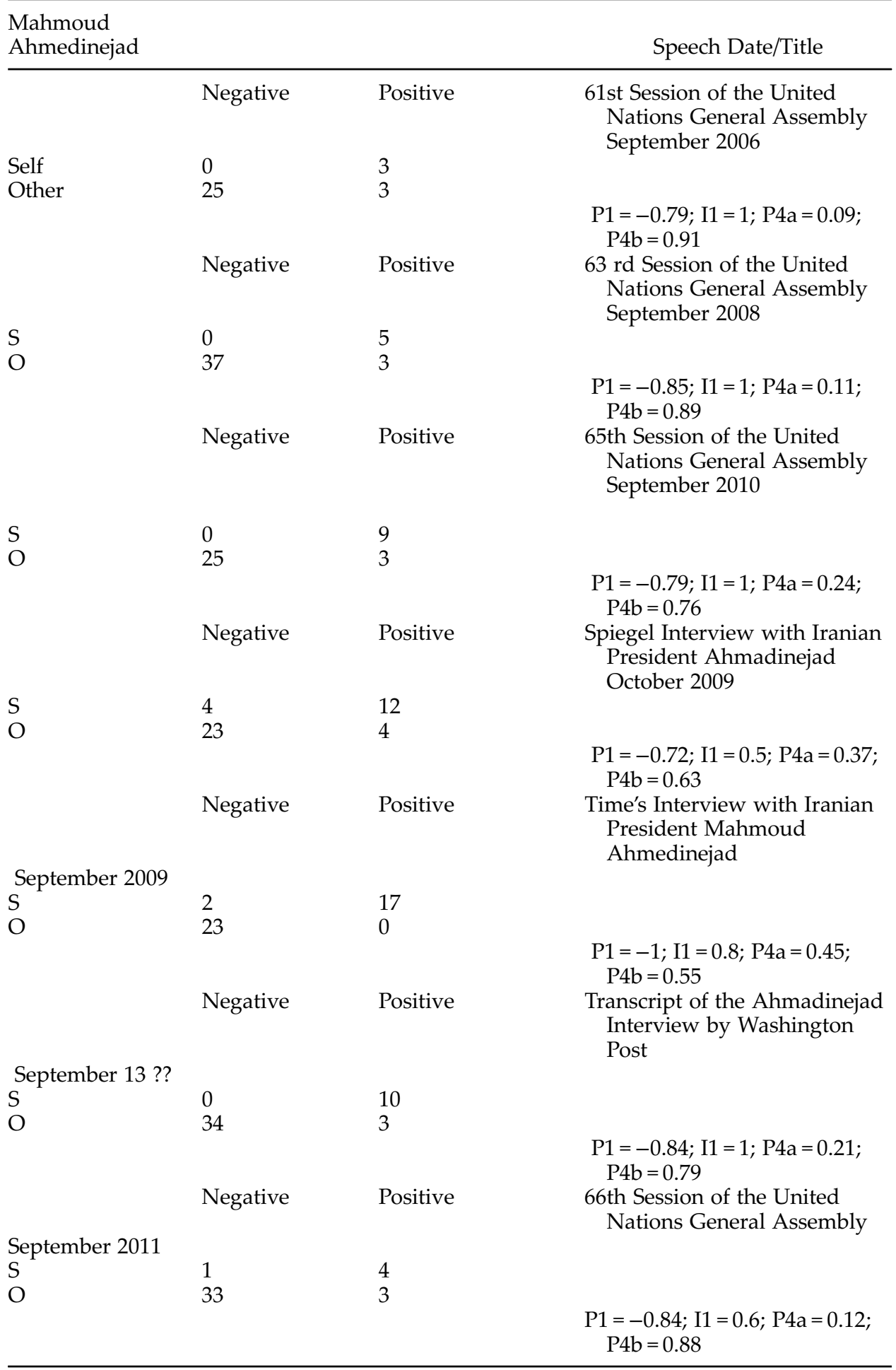


Mashaal, Khaled, “Our People Will Never Rest”, Interview: Spiegel (June 2006).

Mashaal, Khaled, "Hamas' Mesh'al Lays Out New Policy Direction", Interview: Jordanian Al-Sabeel newspaper (September 2010).

Mashaal, Khaled, "On Occupation and Resistance", Interview: Al Quassam website (December 2006).

Mashaal, Khaled, "Resistance is All We Have in Gaza", Interview: Press TV (January 2009).

Mashaal, Khaled, "The Voice of Hamas", Interview: Opendemocracy (November 2010).

Mashaal, Khaled, "Religion, Violence and Chances for Peace", Interview: Ken Livingstone (from NewStatesman) (September 2009).

Mashaal, Khaled, "Khaled Meshaal Interview: Hamas Chief Weighs In on Eve of Peace Talks", Interview: Sharmine Narwani (August 2010).

Note: All speeches are in English. They were translated from Arabic by the publisher.

\begin{tabular}{|c|c|c|c|}
\hline \multirow[t]{2}{*}{$\begin{array}{l}\text { Khaled } \\
\text { Meshaal }\end{array}$} & & & Speech Date/Title \\
\hline & Negative & Positive & $\begin{array}{l}\text { Spiegel Interview with Khaled } \\
\text { Mashaal - 02/06/2006 }\end{array}$ \\
\hline Self & 1 & 11 & \\
\hline Other & 16 & 0 & \\
\hline & Negative & Positive & $\begin{array}{l}\text { Interview with Meshal by Al-Sabeel } \\
\text { newspaper - 25/09/2010 }\end{array}$ \\
\hline S & 0 & 4 & \\
\hline $\mathrm{O}$ & 17 & 1 & \\
\hline & Negative & Positive & $\begin{array}{l}\text { Interview with Meshal in Al Quassam } \\
\text { website - 09/12/2006 }\end{array}$ \\
\hline$S$ & 2 & 8 & \\
\hline $\mathrm{O}$ & 17 & 0 & \\
\hline & Negative & Positive & $\begin{array}{l}\text { Press TV Interview with Khaled } \\
\text { Meshaal - 11/01/2009 }\end{array}$ \\
\hline$S$ & 1 & 6 & \\
\hline $\mathrm{O}$ & 37 & 1 & \\
\hline & Negative & Positive & $\begin{array}{l}\text { The Voice of Hamas Interview with } \\
\text { Hamas Leader Mashall by } \\
\text { Opendemocracy - 5/11/2010 }\end{array}$ \\
\hline$S$ & 1 & 22 & \\
\hline $\mathrm{O}$ & 53 & 4 & \\
\hline & Negative & Positive & $\begin{array}{l}\text { Hamas Leader Interview by Ken } \\
\text { Livingstone (from NewStatesman) } \\
-17 / 09 / 2009\end{array}$ \\
\hline
\end{tabular}


Khaled

Meshaal

Speech Date/Title

\begin{tabular}{llll}
\hline $\mathrm{S}$ & 1 & 13 & \\
$\mathrm{O}$ & 65 & 0 & $\begin{array}{c}\text { Khaled Meshaal Interview conducted } \\
\text { by Sharmine Narwani from Oxford } \\
\text { University }-31 / 08 / 2010\end{array}$ \\
$\mathrm{~S}$ & Negative & Positive & \\
$\mathrm{O}$ & 41 & 22 & \\
\hline
\end{tabular}

